University of Nebraska - Lincoln

DigitalCommons@University of Nebraska - Lincoln

Faculty Publications, Department of Psychology

Psychology, Department of

October 2001

\title{
The credibility of recovered memory testimony: exploring the effects of alleged victim and perpetrator gender
}

\author{
Brian H. Bornstein \\ University of Nebraska-Lincoln, bbornstein2@unl.edu \\ Stephanie L. Muller \\ Louisiana State University
}

Follow this and additional works at: https://digitalcommons.unl.edu/psychfacpub

Part of the Psychiatry and Psychology Commons

Bornstein, Brian H. and Muller, Stephanie L., "The credibility of recovered memory testimony: exploring the effects of alleged victim and perpetrator gender" (2001). Faculty Publications, Department of Psychology. 180.

https://digitalcommons.unl.edu/psychfacpub/180

This Article is brought to you for free and open access by the Psychology, Department of at DigitalCommons@University of Nebraska - Lincoln. It has been accepted for inclusion in Faculty Publications, Department of Psychology by an authorized administrator of DigitalCommons@University of Nebraska - Lincoln. 


\title{
The credibility of recovered memory testimony: exploring the effects of alleged victim and perpetrator gender
}

\author{
Brian H. Bornstein,, ${ }^{*}$, Stephanie L. Muller \\ Department of Psychology, Louisiana State University, Baton Rouge, LA, USA \\ Submitted December 2000; revised April 2001; accepted April 24, 2001
}

\begin{abstract}
Objective: The purpose was to explore the effects of victim/complainant and perpetrator/defendant gender on the impact of recovered memory testimony in criminal sexual abuse trials.

Method: A jury simulation methodology was used. Two hundred forty-six participants read a summary of a sexual abuse trial in which the following three variables were manipulated: the complainant's gender, the defendant's gender, and whether the complainant's memory of the alleged abuse had been "recovered" or remembered all along. Participants reached a verdict and rated the culpability and credibility of the parties.

Results: Compared to a case where the memory of the abuse had always been remembered, recovered memory testimony led to lower perceptions of the defendant's culpability and higher perceptions of the defendant's credibility. In addition, the complainant with recovered memory was viewed as less credible and less likely to be telling the truth. These effects of testimony type (i.e., recovered vs. remembered) were qualified by an interaction with complainant and defendant gender, such that testimony type exerted an effect in cases of alleged heterosexual but not homosexual abuse.
\end{abstract}

Conclusion: The results suggest that mock jurors' judgments in sexual abuse cases reflect their stereotypes about sexual abuse and expectations regarding the relative likelihood of repression in various circumstances.

Keywords: Recovered memory; Child abuse; Juries; Gender effects

* Corresponding author address: Department of Psychology, University of Nebraska, 238 Burnett Hall, Lincoln, NE 68588.

*A portion of this research was presented at the 2000 meeting of the American Psychology-Law Society in New Orleans. 


\section{Introduction}

Although recovered memory therapy is currently less popular than during its heyday in the early 1990 s, it is still used by some therapists who lack an understanding of basic memory processes (Brenneis, 1997; Laurence, Day, \& Gaston, 1998; Lindsay \& Read, 1994; Poole, Lindsay, Memon, \& Bull, 1995; Pope, 1996). Largely as a result of such therapeutic techniques, the number of cases involving claims of recovered memories has increased dramatically (Gothard \& Ivker, 2000; Lindsay \& Read, 1995; Pope, 1996; Schutte, 1994; Wakefield \& Underwager, 1992). For example, according to the False Memory Syndrome Foundation, lout of 16 accused parents have lawsuits filed against them, and approximately 200 recovered memory cases had reached appellate courts as of 1998 (Underwager \& Wakefield, 1998). Because very few cases that are tried are subsequently appealed, this latter figure represents a very conservative estimate of the actual number of recovered memory cases, but it nonetheless reflects their significance within the legal community.

Although the recent adoption of more stringent criteria for the admission of expert scientific testimony (i.e., the Daubert standard, established in Daubert v. Merrell Dow Pharmaceuticals, 1993) has greatly restricted alleged victims' ability to make recovered memory claims in court, a number of judicial decisions have nonetheless permitted recovered memory testimony (Gothard \& Ivker, 2000). Moreover, the recovered memory movement has now spawned a second generation of cases, in which individuals accused of abuse have filed suit against the alleged victims' therapists, claiming that the therapists "implanted" false memories in their clients (Gothard \& Ivker, 2000; Underwager \& Wakefield, 1998). Thus testimony about repression and the plausibility of recovered memory is likely to be an issue of continuing legal importance.

Several factors have been found to influence the believability of recovered memory testimony in studies involving mock juror decisions in both criminal and civil cases. Most prominently, female mock jurors are more sympathetic than males to claims of recovered memory (Griffith, 1999; Griffith, Libkumen, \& Poole, 1998; Loftus, Weingardt, \& Hoffman, 1993). Females' tendency to respond more favorably than males persists across various ethnic backgrounds, different abuse contexts, such as incest or satanic ritual abuse (Schutte, 1994), and variations in the victim's age (Golding, Sanchez, \& Sego, 1999; Golding, Sego, Sanchez, \& Hasemann, 1995).

Although several studies have established effects of participant gender in recovered memory cases, only two studies have investigated the effects of manipulating victim gender on mock juror judgments. Using a mock criminal case in which the victim brought a charge of sexual abuse 10 years after the alleged event occurred, Clark and Nightingale (1997) found an interaction between victim gender and the victim's testimony-that is, whether the abuse was recovered during therapy 10 years later or was merely not reported until that time. Specifically, a male victim claiming repression was perceived as less credible than a male who did not claim repression. A male victim claiming repression was also perceived as less credible than a female victim, regardless of whether or not the female's memory of the event had been recovered. These credibility differences were accompanied by differences in participants' verdicts. ForsterLee and colleagues (ForsterLee, Horowitz, Ho, ForsterLee, \& McGovern, 1999) also manipulated victim gender, but within the context of a mock civil trial. Supporting other research indicating mock ju- 
rors' skepticism about recovered memories, female victims were compensated more when their testimony was remembered (but kept secret) than when it was recovered, though this effect was not significant for male victims.

Taken together, these two studies of victim gender indicate that attention must be paid to the alleged victim's gender in recovered memory cases. The lack of attention to juror response to male victims of sexual abuse reflects the state of the field as a whole (Reinhart, 1987), leading Holmes and Slap (1998) to conclude that sexual abuse of boys is "underreported, under-recognized, and under-treated" (p. 1860). Importantly, however, they also concluded that it is far from uncommon; prevalence estimates ranged from $4 \%$ to $76 \%$, with severe long-term potential effects (Hilton \& Mezey, 1996; Reinhart, 1987).

Whereas little research has addressed the effect of victim gender, none of the extant research on mock jurors' response to recovered memory cases has addressed the possible role played by the gender of the alleged perpetrator. All of the jury simulations cited above have employed a male (civil or criminal) defendant. This omission is puzzling, in light of the sizable minority of sexual abuse cases in which the perpetrator is a female (Faller, 1987). For example, Wakefield and Underwager (1992) found that mothers were accused along with fathers in fully one-third of cases in which parents had been accused of abuse by their adult children in the wake of recovered memories, and Holmes and Slap (1998) reported that up to half of the perpetrators of sexual abuse against boys were female. Importantly, while abuse by male and female perpetrators does not differ in severity (Rudin, Zalewski, \& Bodmer-Turner, 1995), it does differ in certain other characteristics, such as the gender of the victim. Male and female perpetrators are both more likely to abuse girls than boys, yet boys comprise a higher proportion of female perpetrators' victims (Faller, 1987; Rudin et al., 1995).

The purpose of the present study was to make an exploratory attempt to investigate further the effects of alleged victim (i.e., complainant) and perpetrator (i.e., defendant) gender on the impact of recovered memory testimony in a simulated criminal trial (the research is described as exploratory because it included only female participants, to keep the research design manageable, and because mock juror gender differences are already well established). Male complainants were expected to be less credible than female complainants, as females are the stereotypical victims of sexual abuse. On the other hand, female defendants should be rated as more credible than male defendants because they go against the stereotype for child sexual abuse. Manipulating both complainant and defendant gender also affords the opportunity to assess mock jurors' judgments in the context of homosexual versus heterosexual abuse. Because heterosexual abuse is considered more serious for girls, but homosexual abuse is considered more serious for boys (Finkelhor, 1984), male and female claims of repression might be perceived as differentially plausible in cases of homosexual versus heterosexual abuse.

\section{Methods}

\section{Participants}

Two hundred forty-six female undergraduates completed the experiment, for which they received extra course credit. Two participants were excluded for failing a comprehension quiz, leaving a final sample of 244 participants (Mdn age $=19)$. 
Materials and design

The trial summary (modeled after that used by Loftus et al., 1993) described a criminal case of child sexual abuse, in which the 23-year-old complainant alleged abuse by a parent that had occurred between the ages of 10 and 12; hence, the delay in reporting the alleged abuse was approximately 10 years. The summary described the allegation as "memories of five specific incidents of sexual assault (e.g., fondling)." The parent (subsequently the defendant) denied the allegation. The summary varied three factors between participants: the complainant's testimony (recovered vs. remembered but not previously told), the complain-ant's gender, and the defendant's gender, resulting in a $2 \times 2 \times 2$ design. There were 27 to 40 participants per cell.

The memory of the abuse came out in the course of the complainant's therapy for depression and bulimia. In the recovered testimony condition, memory of the abuse was described as having been repressed and first recovered during therapy. In the remembered testimony condition, the abuse was described as having been always remembered but not admitted to anyone until therapy. For each of these conditions, the complainant's and parent/defendant's genders were varied.

\section{Procedure}

Participants were first told that they would be reading testimony from a criminal trial and making a verdict judgment. They were then briefed on the definition of reasonable doubt and the criteria that must be met for a sexual assault conviction. Before reading the trial summary, their beliefs about repression were assessed by asking them to rate, on a 7-point scale, 2 items: I) how credible they found news stories of repressed memories of child abuse, and 2) how certain they were that repression occurs.

After reading the trial summary, participants provided basic demographic information and completed a comprehension quiz consisting of four multiple-choice questions about the content of the trial testimony. They were then instructed again on the reasonable doubt standard and the legal definition of sexual assault before making the following judgments:

1. Ratings of the alleged victim's and perpetrator's credibility, on 7-point scales;

2. Perceptions of the alleged victim's testimony, assessed by having participants distribute $100 \%$ among the probabilities that the defendant was: 1) deliberately lying, 2) honestly mistaken, or 3) telling the truth (Loftus et al., 1993);

3. A verdict of guilty or not guilty; and

4. A confidence rating in their verdict (1-4).

Finally, participants were asked several open-ended questions allowing them to explain their verdict choice, and were asked a second time to rate their beliefs about repression (the free-response data were not very informative and are therefore not reported here). The entire procedure took $15 \mathrm{~min}$ to $30 \mathrm{~min}$, after which participants were debriefed and given their extra credit. 
Table 1

Mean defendant culpability ratings

\begin{tabular}{lr}
\hline Variables & Culpability \\
\hline Testimony & \\
$\quad$ Recovered & $1.63(2.39) *$ \\
$\quad$ Remembered & $.30(2.79)$ \\
Defendant gender & $.79(2.69)$ \\
$\quad$ Male & $1.21(2.63)$ \\
Female & $.74(2.75)$ \\
Complainant gender & $1.27(2.55)$ \\
$\quad$ Fale & 1.27 \\
\hline
\end{tabular}

Note. The scale ranged from -4 (highly confident of a guilty verdict) to +4 (highly confident of a not guilty verdict), so higher values indicate less culpability. Values enclosed in parentheses represent $S D$.

$* p<.001$; other main effects nonsignificant.

\section{Results}

\section{Guilt judgments}

Overall, $27.5 \%$ of participants found the defendant guilty. A "culpability index" (Bottoms \& Goodman, 1994; Crowley, 0' Callaghan, \& Ball, 1994) was created by combining participants' confidence ratings with their guilty/not guilty verdicts, to create a more sensitive 8-point scale (i.e., -4 indicated high confidence in a guilty verdict, and +4 high confidence in a not guilty verdict; see Table 1 ).

Culpability was influenced by type of testimony. Participants found the defendant less culpable when the testimony involved recovered memories than when it did not, $F(1,236)=15.36, p<.001$. There was also a significant 3-way interaction among testimony type, complainant gender, and defendant gender, $F$ $(1,236)=4.77, p<.05$. The interaction was examined by conducting tests of the simple effect of testimony type for each combination of complainant and defendant gender (Maxwell \& Delaney, 1990; see Fig. 1). These comparisons showed that the effect of testimony type was significant in cases of alleged heterosexual abuse, $t s>2.2$, ps $<.05$, but not in cases of alleged homosexual abuse, $t s<1.9$, $p s>.05$. In other words, the defendant accused of homosexual abuse was perceived as equally culpable whether the complainant's memory of the abuse was recovered or remembered, but the defendant accused of heterosexual abuse was perceived as more culpable when the complainant's memory was remembered than when it was recovered.

\section{Credibility}

Participants' perceptions of the defendant's and complainant's credibility are presented in Table 2. Defendant credibility was significantly influenced by type of testimony, with the defendant viewed as significantly more credible when the memory was recovered than when it was remembered, $F(1,236)=$ $10.98, p<.01$. Conversely, ratings of the complainant's credibility were significantly higher when the testimony was remembered than when it was recovered. 


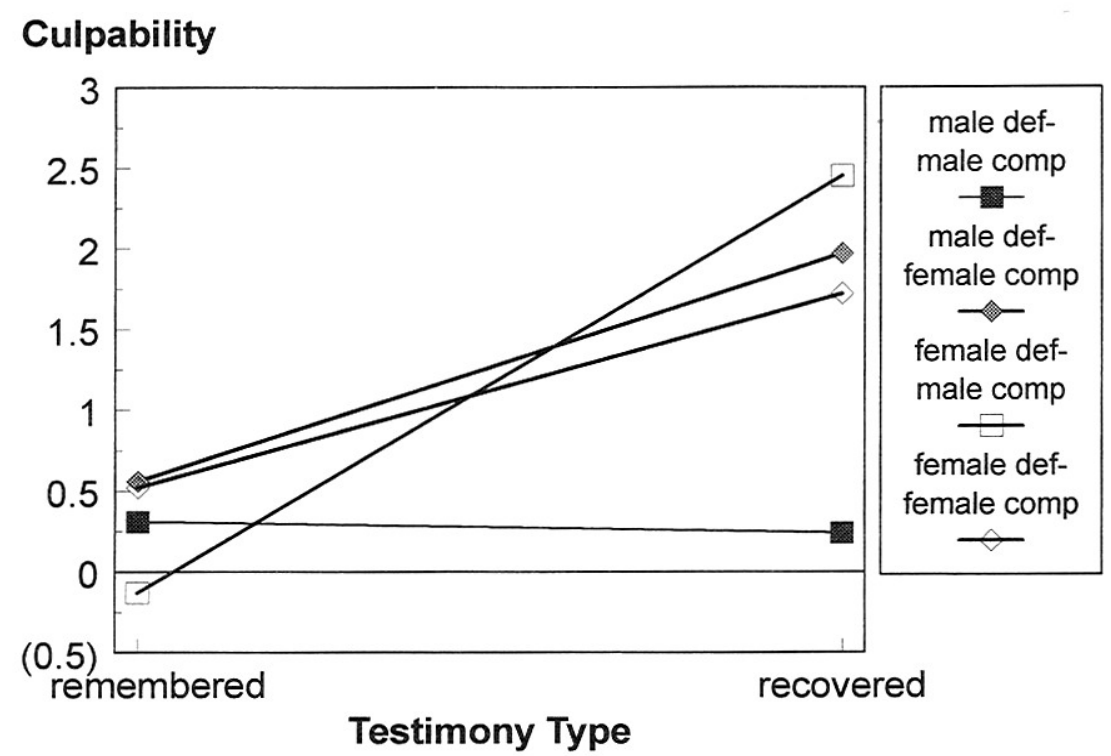

Fig. 1. Mean defendant culpability ratings as a function of defendant (def) gender, complainant (comp) gender, and testimony type. Higher scores indicate lower perceived culpability.

recovered, $F(1,236)=11.63, p<.01$. There were no other significant main effects on credibility of the alleged perpetrator or victim, $F s(1,236)<3.03$.

As with the guilt judgments, there was a significant 3-way interaction on the complainant's perceived credibility among testimony type, complainant gender, and defendant gender, $F(1,236)=6.00, p<.05$ (see Fig. 2 ).

Table 2

Mean ratings of defendant and complainant credibility and complainant's truthfulness

\begin{tabular}{llll}
\hline Variables & $\begin{array}{l}\text { Defendant } \\
\text { credibility }\end{array}$ & $\begin{array}{l}\text { Complainant } \\
\text { credibility }\end{array}$ & $\begin{array}{l}\text { Complainant } \\
\text { truthfulness }\end{array}$ \\
\hline $\begin{array}{l}\text { Testimony } \\
\text { Recovered }\end{array}$ & $4.27(1.16)^{*}$ & $4.21(1.34)^{*}$ & $55.91(28.56)^{*}$ \\
$\quad$ Remembered & $3.77(1.18)$ & $4.79(1.21)$ & $40.42(25.01)$ \\
$\begin{array}{l}\text { Defendant } \\
\text { gender }\end{array}$ & & & \\
$\quad$ Male & $3.91(1.20)$ & $4.62(1.26)$ & $51.28(28.50)^{* * *}$ \\
$\quad$ Female & $4.15(1.18)$ & $4.34(1.35)$ & $44.26(26.74)$ \\
Complainant & & & \\
$\quad$ gender & $3.98(1.21)$ & $4.64(1.27)$ & $51.61(28.06)^{* * *}$ \\
$\quad$ Male & $4.09(1.17)$ & $4.32(1.34)$ & $43.77(27.03)$ \\
$\quad$ Female & & & \\
\hline
\end{tabular}

Note. Credibility ratings are on a scale from 1 (low) to 7 (high); truthfulness ratings are out of 100 . Values enclosed in parentheses represent $S D$.

$* p<.01$,

$* * p<.05$; other main effects nonsignificant. 


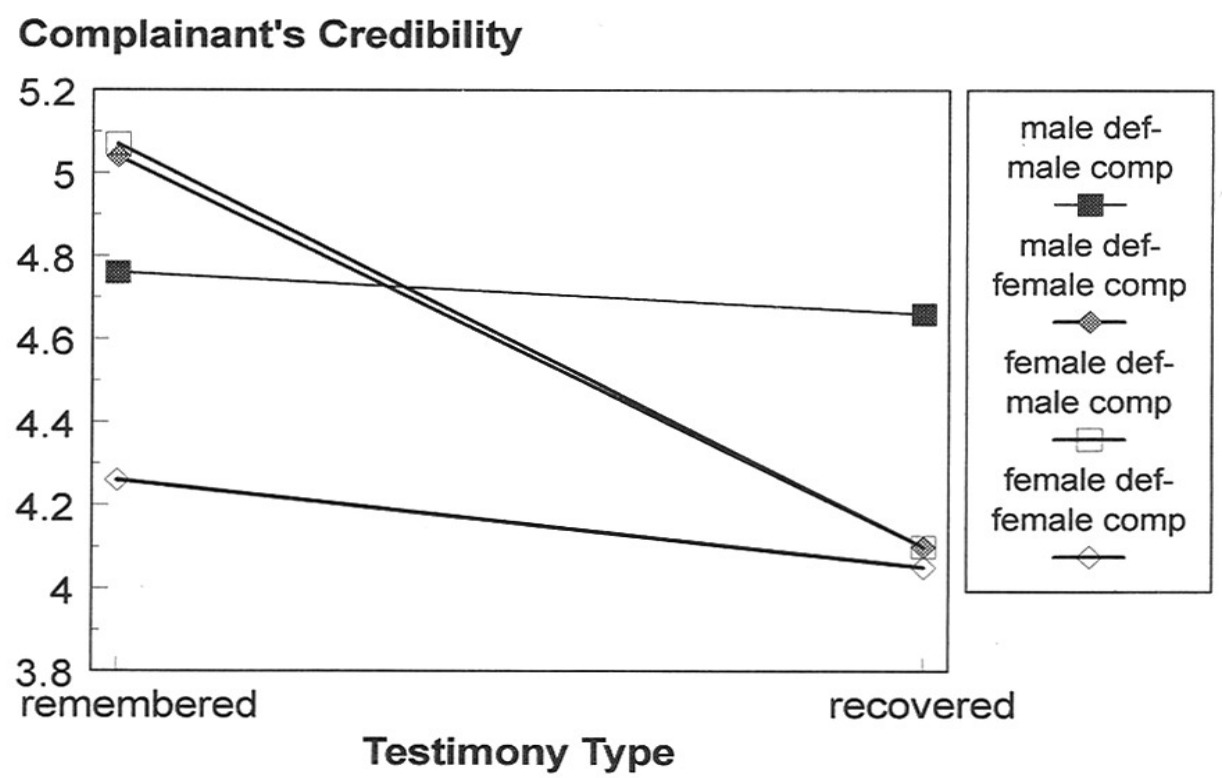

Fig. 2. Mean ratings of the complainant's credibility as a function of defendant (def) gender, complainant (comp) gender, and testimony type. Higher scores indicate higher perceived credibility.

$F(1,236)=6.00, p<.05$ (see Fig. 2). The interaction mirrored the pattern obtained for participants' guilt judgments: The effect of testimony type was significant in cases of alleged heterosexual abuse, $t s>2.8$, $p s<.01$, but not in cases of alleged homosexual abuse, $t s<1, p s>.05$. In other words, both male and female alleged victims of homosexual abuse were perceived as equally credible whether their memory of the abuse was recovered or remembered, but male and female alleged victims of heterosexual abuse were perceived as more credible when their memory was remembered than when it was recovered.

The complainant's credibility was also assessed by asking participants to estimate the probability that the complainant was lying, honestly mistaken, or telling the truth. Overall, participants perceived the complainant as most likely to be telling the truth $(M=47.59$, SD $=27.76)$, slightly less likely to be mistaken $(M=42.70, \mathrm{SD}=25.45)$, and unlikely to be lying $(M=10.57, \mathrm{SD}=13.06)$. As responses to these questions had to add up to 100, they provided redundant information. Therefore, only the analyses of perceived truthfulness are reported here. The perception of the complainant's truthfulness was significantly influenced by all three factors. The complainant was viewed as more truthful when the complainant was male, $F(1,236)=4.84, p<.05$, when the defendant was male, $F(1,236)=4.67, p<.05$, and when the testimony was remembered rather than recovered, $F(1,236)=20.64, p<.01$ (see Table 2).

A significant 3-way interaction among testimony type, defendant, and complainant gender indicated that participants' perception of the complainant's truthfulness was lower for recovered than for remembered testimony in instances of heterosexual abuse, $t s>4.4, p s<.001$, but was unaffected by testimony 
type in instances of homosexual abuse, $t s<1, p s>.05$. This pattern of effects was the same as that observed in participants' defendant culpability and complainant credibility judgments.

\section{Repression beliefs}

Responses to the two questions assessing repression beliefs were positively correlated both pre-trial $(r$ $=.34, p<.001)$ and post-trial $(r=.44, p<.001)$. The responses were therefore summed to create a single "belief in repression" index, which ranged from 2 to 14 . Overall, participants rated the concept of repression as significantly less believable after the trial than beforehand, $t(239)=3.05, p<.001$ (pretrial: $M=$ $10.18, S D=1.54$; post-trial: $M=9.95, S D=1.78$ ).

\section{Discussion}

The present study investigated the influence of alleged victim and perpetrator gender on mock juror decisions in cases involving recovered memories. Compared to complainants who had remembered the abuse all along, complainants who testified about a recovered memory were perceived as less credible and less likely to be telling the truth. The defendant was also more likely to be acquitted when the complainant's testimony was based on a recovered memory than when the memory had always been accessible. Thus, although people may tend to accept the general concepts of repression and recovered memory (Golding, Sanchez, \& Sego, 1996), they maintain a healthy skepticism about these concepts when they are introduced at trial (e.g., ForsterLee et al., 1999; Key, Warren, \& Ross, 1996; Loftus et al., 1993). This skepticism is evident also in the low overall rate $(27.5 \%)$ of defendant convictions.

Past research on recovered memory trials has focused upon the stereotypical female complainant and male defendant. In reality, sexual abuse of boys is far from uncommon (Hilton \& Mezey, 1996; Holmes \& Slap, 1998; Reinhart, 1987), and women frequently number among the ranks of the abusers (Faller, 1987; Holmes \& Slap, 1998; Rudin et al., 1995; Wakefield \& Underwager, 1992). The alleged victim in the present study was rated as more truthful when the defendant was male than when the defendant was female. This result could reflect a reliance on stereotypes of males as the more typical abusers. However, the same gender difference was not manifested in ratings of the defendant's overall credibility or degree of guilt, suggesting that if such a stereotype does exist, it is limited in its scope.

Consistent with previous research on alleged victim gender (Clark \& Nightingale, 1997; ForsterLee et al., 1999), there was no differential treatment of male and female complainants across the board, with the exception of males being perceived as more truthful. Instead, the effect of complainant gender was largely moderated by the nature of the abuse-that is, whether it was homosexual or heterosexual. Previous research on jurors' reactions to recovered memory testimony reflects considerable variation in terms of the relationship between alleged victim and perpetrator and the nature of the abuse. People's naive beliefs about repressed memory vary widely (Golding et al., 1996), and it is likely that the believability of a particular recovered memory claim depends to some extent on details of the claim itself (Schutte, 1994).

A claim of repression would be differentially plausible if, for instance, homosexual abuse were per- 
ceived as more traumatic than heterosexual abuse. There is some evidence that such a stereotype exists for male sexual abuse victims (Finkelhor, 1984), and the present results suggest that such a stereotype-at least for female participants-extends to female victims as well. Variations in other aspects of the nature 'Of the sexual abuse, such as the frequency of occurrence (i.e., a single occurrence vs. chronic abuse), the identity of the abuser (i.e., stranger, family friend, relative), or even the precise acts involved (anal intercourse, oral intercourse, fondling, etc.) are ripe areas for future investigation to determine whether the believability of recovered memory varies across these different situations as a function of their typicality.

ForsterLee et al. (1999), while also finding no main effects of complainant gender, found that it interacted with the type of testimony. Participants awarded greater compensation to female plaintiffs who had remembered the abuse than to those who had a recovered memory, while male plaintiffs were compensated equally regardless of their testimony. This interaction is consistent with the results of the present study, in which an alleged female victim of a male abuser was perceived as more credible-and elicited stronger guilt judgments-when her testimony was remembered than when it was recovered, but testimony type had no effect when the alleged victim and perpetrator were both male (the conditions comparable to ForsterLee et al.' s design). The present study extended ForsterLee et al.'s findings by varying alleged perpetrator as well as victim gender. The results suggest that their failure to find an effect of testimony type for male plaintiffs is not because of the plaintiff's gender, per se; rather, mock jurors are not affected by testimony type whenever the alleged victim and perpetrator are the same gender. In cases of heterosexual abuse, on the other hand, we obtained the typical finding that an alleged victim claiming a recovered memory is less credible than an alleged victim whose memory has been accessible but was not reported (e.g., Key et al., 1996; Loftus et al., 1993).

\section{Conclusion}

The present study varied the gender of the purported victim and perpetrator in a simulated sexual assault trial, in conjunction with whether the complainant's testimony was based on a recovered memory or had been remembered previously but unreported. There was a main effect of testimony type, such that complainants claiming to have recovered their memory of the abuse were perceived as less truthful and less credible. Convictions were relatively less likely in these cases as well. The major finding of the present research was the existence of a 3-way interaction among type of testimony, complainant, and defendant gender. The effect of testimony type was present in cases of heterosexual abuse (i.e., male defendantfemale complainant or female defendant-male complainant) but not in cases of homosexual abuse (male defendant-male complainant or female defendant-female complainant). In other words, alleged victims of heterosexual abuse-regardless of their or the defendant's gender-were more credible when their testimony was remembered than when it was recovered, but alleged victims of homosexual abuse were equally credible in both circumstances. 


\section{Acknowledgments}

We are grateful to Janet McDonald for statistical advice, and to David DiLillo for helpful comments on an earlier version of the manuscript.

\section{References}

Bottoms, B. L., \& Goodman, G. S. (1994). Perceptions of children's credibility in sexual assault cases. Journal of Applied Social Psychology, 24, 702-732.

Brenneis, C. B. (1997). Recovered memories of trauma: transferring the present to the past. Madison, WI: International Universities Press.

Clark, H. L., \& Nightingale, N. N. (1997). When jurors consider recovered memory cases: effects of victim and juror gender. Journal of Offender Rehabilitation, 25, 87-104.

Crowley, M. J., O'Callaghan, M. G., \& Ball, P. J. (1994). The juridical impact of psychological expert testimony in a simulated child sexual abuse trial. Law and Human Behavior, 18, 89-105.

Daubert $v$. Merrell Dow Pharmaceuticals, 509 U.S. 579 (1993).

Faller, K. C. (1987). Women who sexually abuse children. Violence and Victims, 2, 263-276.

Finkelhor, D. (1984). Child sexual abuse: new theory and research. New York: Free Press.

ForsterLee, R., Horowitz, I. A, Ho, R., ForsterLee, L., \& McGovern, A. (1999). Community members' perceptions of evidence: the effects of gender in a recovered memory civil trial. Journal of Applied Psychology, 84, 484-495.

Golding, J. M., Sanchez, R. P., \& Sego, S. A. (1996). Do you believe in repressed memories? Professional Psychology: Research and Practice, 27, 429-437.

Golding, J. M., Sanchez, R. P., \& Sego, S. A (1999). Age factors affecting the believability of repressed memories of child sexual assault. Law and Human Behavior, 23, 257-268.

Golding, J. M., Sego, S. A, Sanchez, R. P., \& Hasemann, D. (1995). The believability of repressed memories. Law and Human Behavior, 19, 569-592.

Gothard, S., \& Ivker, N. (2000). The evolving law of alleged delayed memories of childhood sexual abuse. Child Maltreatment, $5,176-189$.

Griffith, J. D. (1999). Repressed memories in the courtroom: trial characteristics affecting mock juror's decision making. American Journal of Forensic Psychology, 17, 5-24.

Griffith, J. D., Libkumen, T. M., \& Poole, D. A. (1998). Repressed memories: the effects of expert testimony on mock juror's decision making. American Journal of Forensic Psychology, 16, 5-23.

Hilton, M. R., \& Mezey, G. C. (1996). Victims and perpetrators of child sexual abuse. British Journal of Psychiatry, 169, 408415.

Holmes, W. c., \& Slap, G. B. (1998). Sexual abuse of boys: definition, prevalence, correlates, sequelae, and management. Journal of the American Medical Association, 280, 1855-1862.

Key, H. G., Warren, A. R., \& Ross, D. F. (1996). Perceptions of repressed memories: a reappraisal. Law and Human Behavior, 20, 555-563.

Laurence, J.-R., Day, D., \& Gaston, L. (1998). From memories of abuse to the abuse of memories. In S. J. Lynn \& K. M. McConkey (Eds.), Truth in memory (pp. 323-346). New York: Guilford.

Lindsay, D. S., \& Read, J. D. (1994). Psychotherapy and memories of childhood sexual abuse: a cognitive perspective. Applied Cognitive Psychology, 8, 281-338.

Lindsay, D. S., \& Read, 1. D. (1995). "Memory work" and recovered memories of childhood sexual abuse: scientific evidence and public, professional, and personal issues. Psychology, Public Policy, \& Law, 1, 846-908.

Loftus, E. F., Weingardt, K. R., \& Hoffman, H. G. (1993). Sleeping memories on trial: reaction to memories that were previously repressed. Expert Evidence, 2, 51-59. 
Maxwell, S. E., \& Delaney, H. D. (1990). Designing experiments and analyzing data: a model comparison perspective. Belmont, CA: Wadsworth. B.H. Bornstein, S.L. Muller/Child Abuse \& Neglect 25 (2001) 1415-1426

Poole, D. A., Lindsay, D. S., Memon, A., \& Bull, R. (1995). Psychotherapy and the recovery of memories of childhood sexual abuse: US and British practitioners' opinions, practices, and experiences. Journal of Consulting and Clinical Psychology, 63, 426-437.

Pope, K. S. (1996). Memory, abuse, and science: questioning claims about the false memory syndrome epidemic. American Psychologist, 51, 957-974.

Reinhart, M. A. (1987). Sexually abused boys. Child Abuse \& Neglect, 11, 229-235.

Rudin, M. M., Zalewski, c., \& Bodmer-Turner, J. (1995). Characteristics of child sexual abuse victims according to perpetrator gender. Child Abuse \& Neglect, 19, 963-973.

Schutte, J. W. (1994). Repressed memory lawsuits: potential verdict predictors. Behavioral Sciences and the Law, 12, $409-416$.

Underwager, R., \& Wakefield, H. (1998). Recovered memories in the courtroom. In S. J. Lynn \& K. M. McConkey (Eds.), Truth in memory (pp. 394-434). New York: Guilford.

Wakefield, H., \& Underwager, R. (1992). Recovered memories of alleged sexual abuse: lawsuits against parents Behavioral Sciences and the Law, 10, 483-507.

\section{Résumé}

Objectif: Le but a été d' explorer les effets du sexe de celui qui a porté plainte cornme victime et de l'agresseur-prévenu sur l'impact du témoignage basé sur des souvenirs retrouvés dans les prociés au criminel concernant des agressions sexuelles.

Méthode: On a utilisé comme méthodologie celle du jury simulé. 246 participants on lu le résumé d'un procés pour agression sexuelle dans lequel les trois variables suivantes étaient manipulées: Ie sexe du plaignant, le sexe du prévenu et le fait que le souvenir de l' agression alléguée par le plaignant avait été "retrouvé" ou qu'il avait été "toujours présent." Les participants ont prononcé un verdict et ont evalue la culpabilité et la crédibilité des parties.

Résultats: Si on compare le cas où le souvenir de l' agression avait toujours persisté avec celui où le témoignage était basé sur un souvenir "retrouvé," on trouve dans celui-ci une perception plus faible de la culpabilité du prévenu et une perception plus élevée de la crédibilité du prévenu. De plus, le plaignant qui a retrouvé des souvenirs est considere comme moins credible et moins susceptible de dire la vérité. Ces effets du type de témoignage (souvenirs retrouvés ou conservés) ont été qualifiés par une interaction entre le sexe du plaignant et du prévenu de telle façon que le type du témoignage a pu exercer un effet dans les cas d'agression hétérosexuelle mais non dans les cas d'agression homosexuelle.

Conclusion: Les résultats suggèrent que les jugements d'un jury simulé dans les cas d'agression sexuelle reflètent des stéréotypes au sujet des agressions sexuelles et des anticipations concernant la probabilité relative d'une répression selon les circonstances.

\section{Resumen}

Objetivo: Explorar los efectos del género de la víctima y del perpetrador en el impacto del testimonio sobre recuerdos recuperados en juicios de abuso sexual.

Método: Se utilizó una metodología de jurado simulado. Un total de 246 participantes leyeron un resumen de un juicio de abuso sexual en el cual fueron manipulados las siguientes tres variables: el género de la víctima, el género del perpetrador y si los recuerdos de la víctima sobre el abuso habían sido record 
ados siempre o habían sido olvidados durante algún tiempo y luego "recuperados." Los participantes debían alcanzar un veredicto y puntuar la culpabilidad.y credibilidad de las partes.

Resultados: En comparación con los casos en los que siempre había habido recuerdo del abuso, el testimonio de los recuerdos "recuperados" produce una menor percepción de culpabilidad y una mayor percepción de credibilidad con respecto al acusado. Además, el supuesto abusado con recuerdos "recuperados" fue visto como menos creíble y menos proclive a decir la verdad. Estos efectos del tipo de testimonio ("recuperado" vs. "siempre recordado") quedaron cualificados por una interacción con el género del acusado y la supuesta victima, de manera que el efecto descrito se observa en casos de abuso sexual heterosexual pero no en casos de abuso sexual homosexual.

Conclusión: Los resultados sugieren que las valoraciones de los jurados en casos de abuso sexual reflejan sus estereotipos acerca del abuso sexual y sus expectativas en relación con la relativa posibilidad de represión. 